Article

\title{
Edifice of Fluvial Terrace Flights, Stacks and Rows
}

\author{
Wolfgang Schirmer \\ Former Department of Geology, Heinrich Heine University Düsseldorf, \\ Wolkenstein 24, D-91320 Ebermannstadt, Germany; schirmer@uni-duesseldorf.de; Tel.: +49-9194-724772
}

Received: 31 August 2020; Accepted: 8 December 2020; Published: 15 December 2020

\begin{abstract}
The paper presents a review of the architecture and structures of river deposits in valleys. A new terminology for some features is included in this review. It presents principles of the fluvial systems with morphological river terraces and fluments (new term for terrace bodies), different stages of the morphological terraces, the texture-the arrangement-of fluments in the form of terrace flights, terrace stacks and terrace rows, and the (inner) structure of a single flument. The contact between the valley fill and the bedrock is named by the new term "pelma". Special topics deal with flument overlaps and insight into the deepest valley fill down to the bedrock. A comparison with other terms of the fluvial inventory is annexed.
\end{abstract}

Keywords: river terrace; flument (terrace body); pelma (contact flument/bedrock); terrace flight; terrace row; flument stack; flument overlap; valley underground

\section{Introduction}

This paper highlights frequent as well as rare situations derived from constructing terrace flights, terrace rows and flument stacks. River terrace flights, stacks and rows are well known and described in detail, e.g., [1-20]. In supplement to these papers, the following explanations separate morphological river terraces and fluments as terrace bodies, highlight texture (arrangement) of terrace flights, terrace stacks and terrace rows, and highlight problems of flument overlap and of the study of the deepest valley fill down to the bedrock. It emphasizes the (inner) structure of the fluments as tools for recognizing single flument portions. Fluments and terraces always are indicated by a name and not numbered, as already stressed by Howard [21,22]. As the focus in this text is given to the architecture of the elements of the valley, only sometimes their genesis, e.g., [23-27], and age determination, e.g., [28,29], are mentioned marginally. In the later part of the paper, selected examples besides the general explanations relate to the Upper Main region in south-eastern Germany (Figure 1). The selection in Central Europe or sometimes in the Rhine-Main River area gives the results a regional character. In comparison to other visited or studied areas in the world, though, e.g., North America or the Orient [30-32], many common features turned out to fit into the given schemes. 


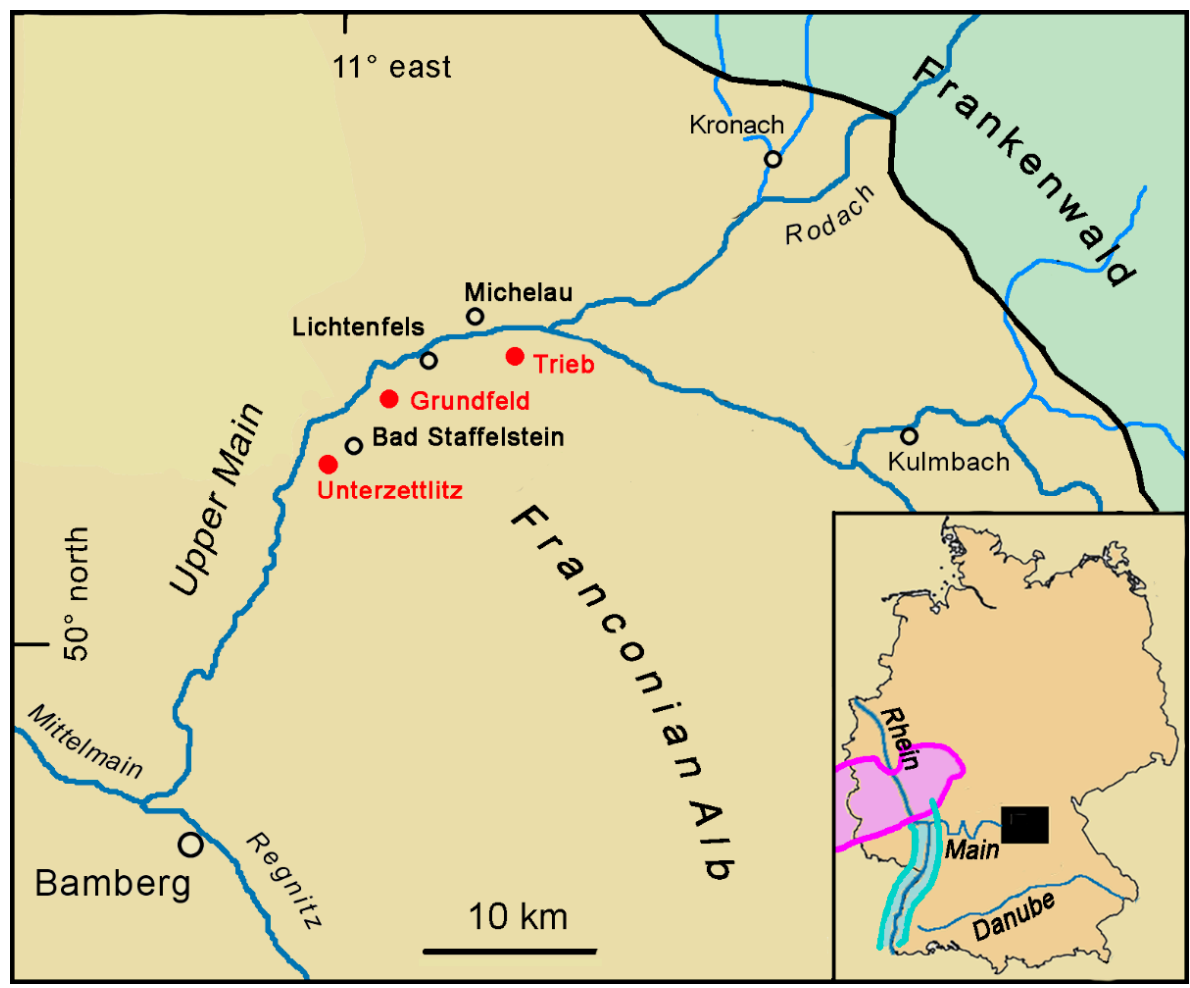

Figure 1. Location map of the Upper Main area/Bavaria. Inset: Map of Germany. Black rectangle= location of this map. Violet: Uplift area of the Rhenish Shield. Green area: Upper Rhine graben.

\section{Materials and Methods}

The following report results from extended and long fieldwork along rivers in the Alpine foreland, the central upland and the northern lowland of Central Europe, North America, and Mesopotamia.

The investigation includes: Mapping in scale 1: 5000, 1: 25,000, separation of morphological terraces, and investigation of their pedological properties, including pedochemical properties. Study of the vertical structure, from the highest fluvial deposits down to the very valley underground at the bedrock, is done case by case using grain size separation of gravel, sand and fines, chemical properties (carbonate, organic carbon, phosphorus, heavy metals), dating by ${ }^{14} \mathrm{C}$, dendrochronology, pollen analysis, and archaeological and historical materials. The Main River valley in southern Germany, to which the focus is frequently given here, gave the most complete insight. From all these studies resulted the general insights into the fluvial valley edifices presented in the following.

\section{Principles of Flument Systems}

\subsection{Flument and Terrace}

Penck [33] tried to separate the morphological "terrace" from the sedimentological "gravel", but used the term terrace for both facts. In this way it is often used until today. Boesch [34] points to the fact that the accumulation body and its topping terrace are mostly not of the same age. Leopold et al. [35] (p. 460) state that the sedimentary deposit of a terrace "should more properly be referred to as a fill, alluvial fill, or alluvial deposit, in order to differentiate it from the topographic form".

Thus, here a distinction is drawn between the sedimentary body and its morphological surface, called terrace. The river deposit is called flument (from Latin flumen = river, stream), a term newly introduced [14] (p. 135). As shown in Figure 2, the structure of the flument in its best preservation shows: basal lag layer, channel deposit, floodplain deposit and floodplain soil. This is a frequent example of the flument structure among many other possibilities. The flument is topped morphologically by the river terrace that is a mere surface feature. 


\section{fluviatile series}

floodplain soil

- - - - -

floodplain sediment

floodplain channel

sediment

channel sediment

WSch
2020

vertically aggraded flument (V flument)

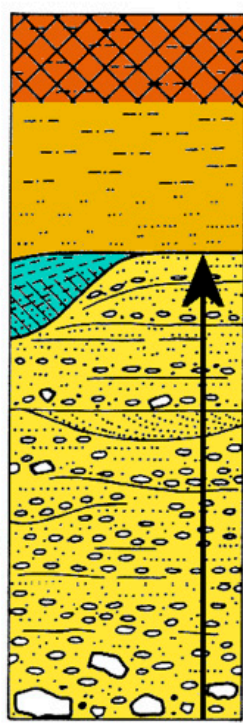

silty to

sandy,

graded

back-

swamp

small

sand

increase

V gravel

lag

facies lateral accretion flument

(L flument)

Figure 2. Flument structures. A complete flument is composed of all members of the fluviatile series.

The skeleton gravel is marked by black pebbles in all figures of this paper.

In case the flument rests upon the bedrock the contact between the flument and the bedrock is called pelma (from Greek pélma = sole), a term introduced recently [15] (p. 70) (Figure 3). The basal bedrock contact is the ground pelma, and the lateral bedrock contact is the wall pelma. Ground pelma has a certain affinity to the term "strath": it does not conform to strath sensu, Bucher's original definition [36]. The term is discussed by various redefinitions, e.g., [21,26,37] (see Section 7).

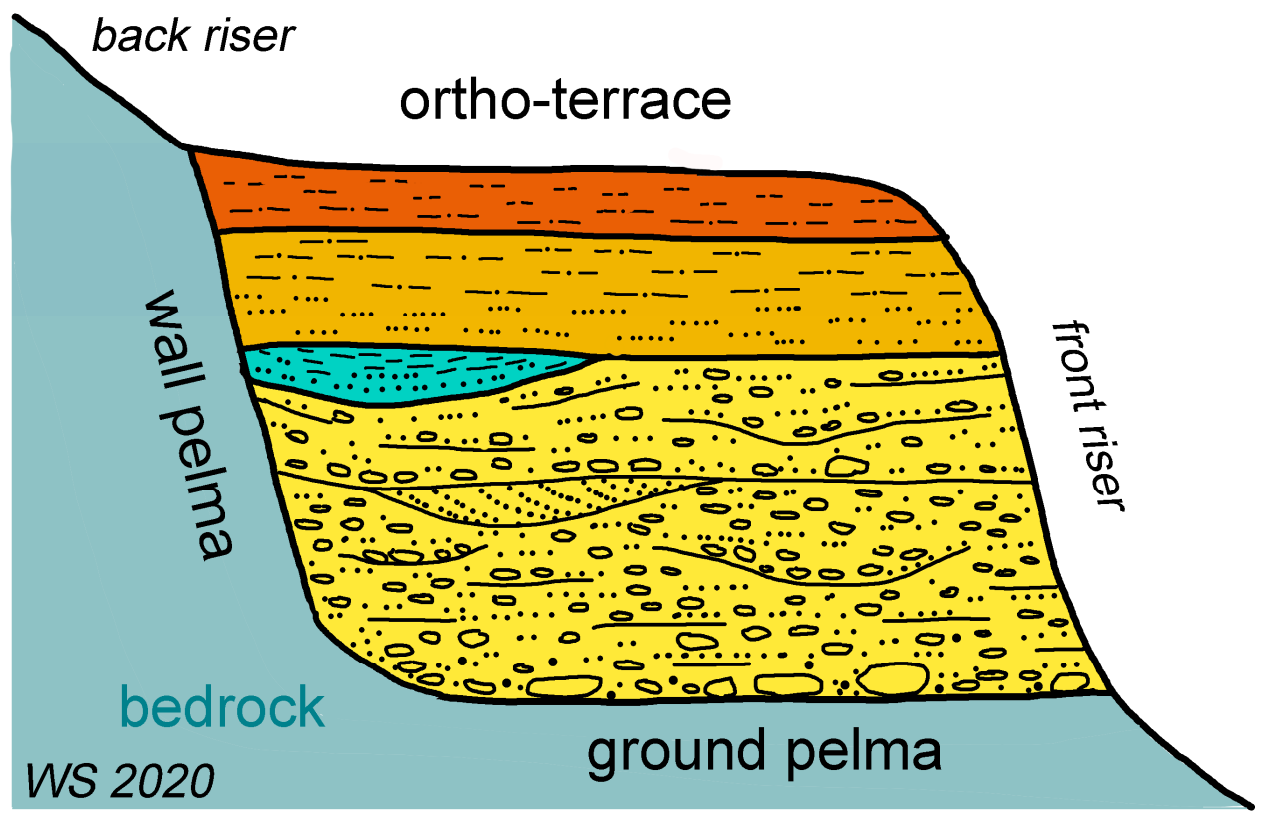

Figure 3. Ortho-terrace and pelma: A complete flument is bounded on top by the ortho-terrace as tread, at the basal bedrock contact by the ground pelma, and at the lateral bedrock contact by the wall pelma. (The flument exemplarily is figured as V-flument). 


\subsection{Types of Fluments}

The inner structure of the flument simplified shows two main sedimentary types, the vertical aggradation type and the lateral accretion type (Figure 2) - though it must be remarked that these sedimentary types are two of many possibilities. The first type mostly results from braided reaches, the latter from the meandering parts within a river course. A flument of the lateral accretion type is called L-flument (according to Lateral), that of the vertical aggradation type, V-flument (according to Vertical) [9] (p. 25). The L-flument at its base is characterized by skeleton gravel (open work gravel).

\subsection{Stages of River Terraces}

The geometry of river terraces varies significantly with age. The surface of a flument is called a terrace as soon as the flument has been cut by the river, forming a lower situated younger river plain, leaving a downward step (front riser) toward the new river plain, and leaving an upward step (back riser) toward the slope of the valley edge. In a case where the flument reaches its mature stage or has already fulfilled its mature stage, the topping terrace (tread) is called an ortho-terrace (Figure 3). The ortho-terrace is as old as the last river deposits upon the flument. Soil formation may continue upon the ortho-terrace.

An age of an ortho-terrace may cover a long period. The frequency of flooding in the floodplain is normally decreasing with the upgrowth of the flood plain. Thus, the intermittent periods between the floods become longer. These periods are the chance for soil formation within the floodplain. The longer the breaks between flood events, the stronger the soil formation on the flood deposits. Consequently, soil formation is part of the decreasing floodplain sedimentation (threshold of the critical power in the stream [18] (p. 10)). A further participation of soils in floodplain deposits is the intermingling of relocated soil material called fluvisoliment [9] (p. 27). Additionally, synpedological sediment deposition occurs.

Upon older fluments, the ortho-terrace slowly gets eroded. The erosional surface still may appear as a terrace, but is an inclined plane that cuts the flument diagonally (Figure 4). This terrace is younger than the ortho-terrace and becomes younger and younger through time. It is called here a dia-terrace-from the diagonal erosional cut through the flument.
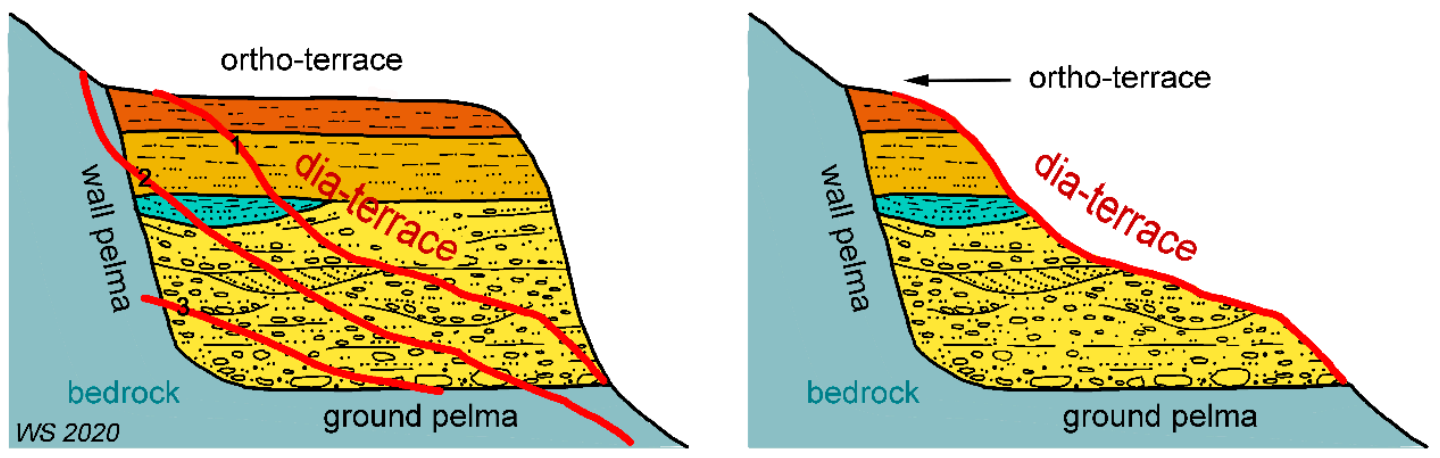

Figure 4. Changing geometry of terraces. Dia-terrace: a complete flument when diagonally cut (red lines) generates dia-terraces. Shown are three random stages (1-3) of dia-terraces, leaving behind more or less volume of the previous flument.

In Figure 4, the dia-terrace shows different stages (1-3) of erosion drawn in red. The upper stage (1) allows one to determine the position of the ortho-terrace by the terrace remnant preserved at the outer edge of the previous terrace. Additionally, all members of the flument remain preserved. The middle stage (2) leaves behind remnants of the floodplain edge channel. By this, experiences of floodplain thicknesses of the investigation area should allow one to calculate the former level of the ortho-terrace. The lower stage (3) can only indicate the terrace pelma. Moreover, this stage (3) prevents one's identifying an L- or V-flument. 
If the erosion has reached the pelma leaving only a lag layer above the bedrock, it is called a pelma-terrace (Figure 5). The pelma terrace may have a back riser (Figure 5b) or may be isolated (Figure 5c). The lag layer of a pelma terrace is mostly not more than an eluvial loose litter of pebbles.

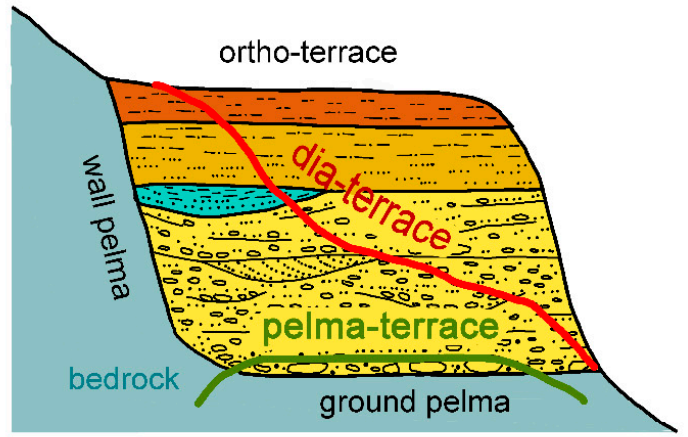

a

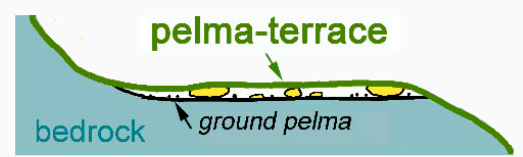

b

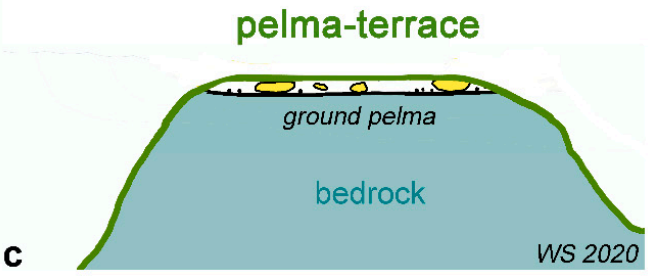

Figure 5. Pelma-terrace: a complete flument (a) eroded down (green line) to the basal facies leaving only the lag layer and the ground pelma (contact of the basal facies with the bedrock), (b) with a backwall, (c) crowning a hilltop. Normally, the pelma-terrace deposit is a loose litter of pebbles.

As a result, younger fluments of an incised valley can be followed and compared by the elevation of their ortho-terraces, older fluments by their dia-terraces. Sometimes, they tend more to be parallelized by their ground pelma/strath. Ortho-, dia-, and pelma-terraces may occur as paired or unpaired terraces [38].

\section{Texture (Arrangement) of Fluments}

Within a sequence of fluments or terraces, they may be cut in the bedrock or in older fluments: cut-in fluments or cut-in terraces. If the base, walls, and terrace of a flument are cut into a preceding flument, it is called a nested flument/terrace.

In addition, if a cut-in terrace cuts a flument with its bedrock beneath, or cuts the bare bedrock, it is called a strath terrace, after the strath, which is the name for the contact flument upon the bedrock or the bare fluvial cut bedrock (([18] p. 8), ([26] p. 32), [36,39,40]); cf. Section 7.3.

Fluments may form rows, one flument deposited beside a preceding one: row fluments with row terraces [9].

Fluments may form stacks by overlapping and/or completely superimposing on a preceding flument: overlap flument, stacked flument.

Preferentially, there occur three major flument textures within valleys: flument/terrace flights (staircases), flument/terrace rows, and flument stacks. Actually, all forms may be mixed within the valley edifice. Whether staircase, row, or stack, all are controlled by tectonic uplift, subsidence, or equilibrium. In addition, the trend to more or less flument deposition is controlled by the manifold climatical alterations of glacial and interglacial periods during the Quaternary, e.g., [23,28,29]. 


\subsection{Flument Flights Respectively Terrace Flights}

These are the result of rhythmical cut-and-fill processes of fluvial incision and fluvial deposition [41,42]. Terrace flights occur in areas of subsided water level, caused either by subsided sea level or by land uplift. The latter is the case shown here. The highest situated terrace of a flight is the oldest; the lowest is the youngest terrace. This is the normal expectation. However, it need not be so, as shown later. Examples for terrace/flument flights are given from the Middle Rhine River within the uplift area of the Rhenish Shield since the Oligocene (Figure 6; compare also the fine changes in [4]). Within this flight, most fluments are cut-in fluments. The Holocene floodplain fluments are nested in the Late Pleistocene fluments. A next terrace flight is given from the Main River (Figure 7). This flight is conspicuously interrupted by a thick flument stack (Section 4.2). Additionally, herein several fluments appear to be nested.

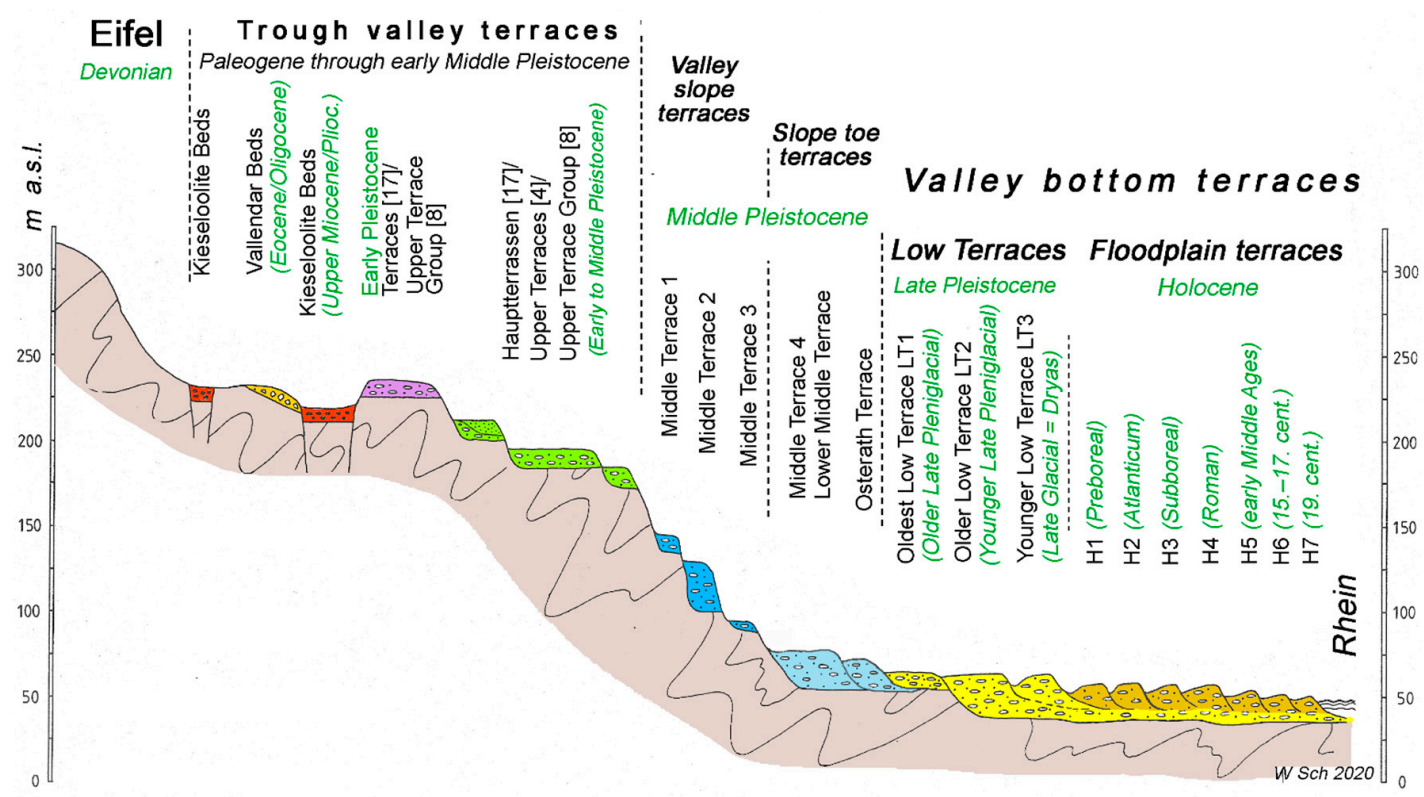

Figure 6. Scheme: Flument/terrace flight of the Middle Rhine River within the Rhenish Shield. Eifel = mountains adjoining the Rhine valley to the west. Vertical scale exaggerated. Location: The uplifted Rhenish Shield (violet area in Figure 1).

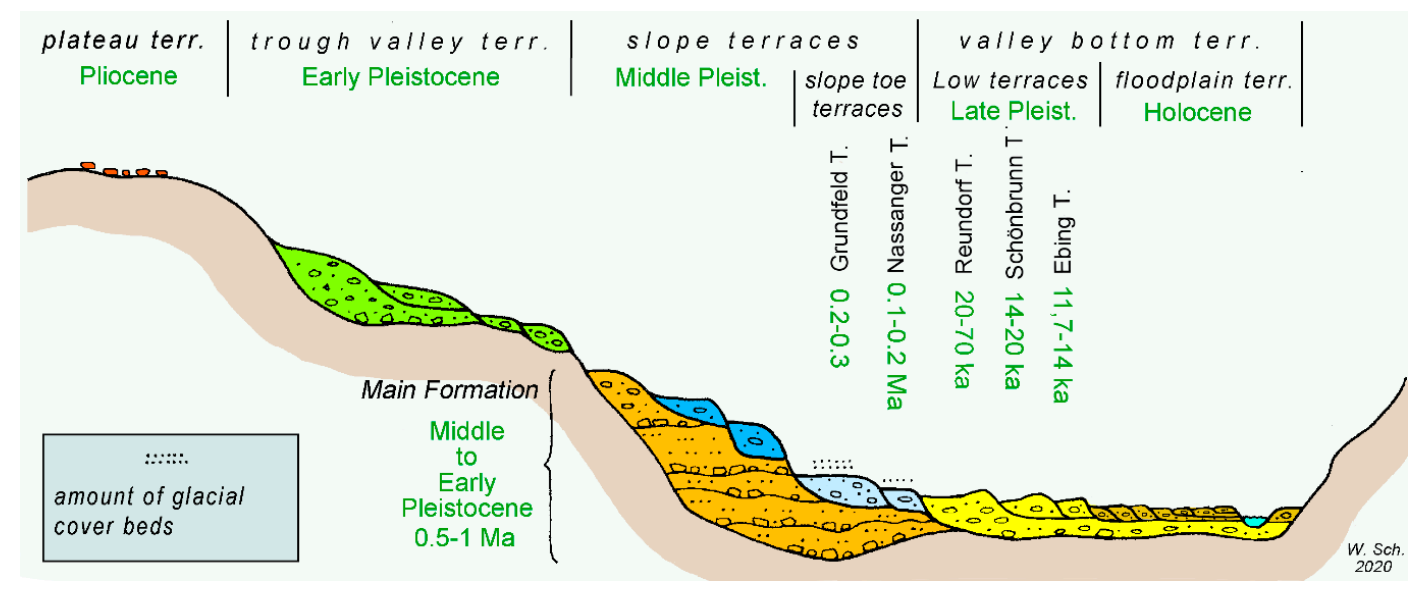

Figure 7. Scheme of the flument/terrace flight of the Main River and adjoining rivers in Central Europe. Not to scale. For the age of the Holocene terraces, see Figure 9. Location: Whole Main River. 


\subsection{Flument Stacks}

Flument stacks are the result of superposition of fluments. Within the stack, in contrast to the terrace flight, the lowest flument is the oldest, and the uppermost flument is the youngest (Figure 8 and Main Formation in Figure 7) [43]. Figure 7 shows a change from flument flight to flument stack and back to flight. Its interpretation is: in the Early Pleistocene ( 1.7 Ma [44], p. 333), the Upper Rhine Graben (Figure 1) started to subside more strongly. Thus, the Main River had to incise deeply to level with the receiving water of the Rhine. When the downward movement of the Upper Rhine Graben tapered off by ca. $1 \mathrm{Ma}$ [43], the Main River with its clayey-sandy hinterland could form the rhythmical aggradation of the 30-60 m thick stack of the Main Formation. By further uplift of Southern Central Europe ( 0.5 Ma [44]), the stack was cut to continue the terrace flight until today.

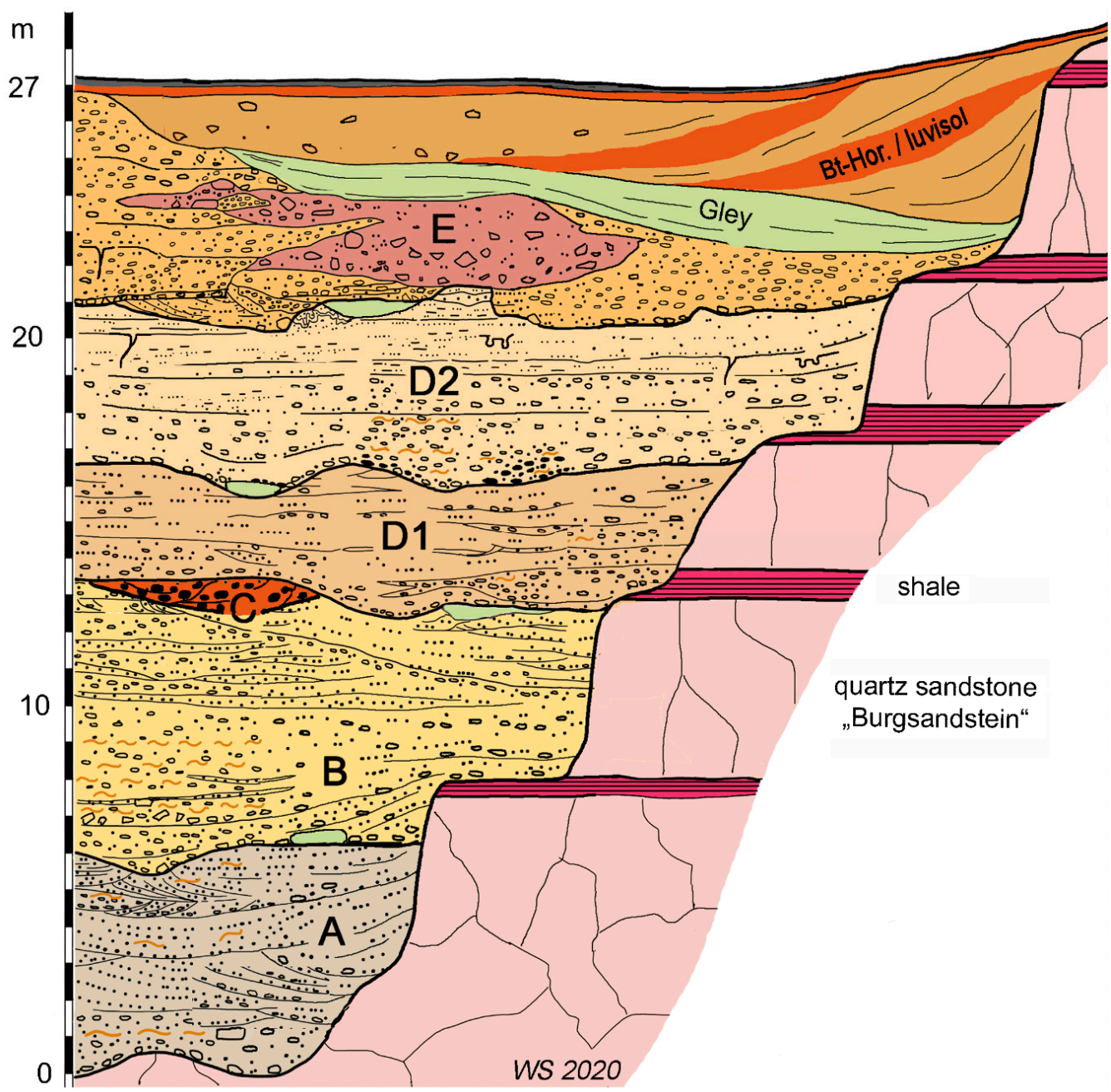

Figure 8. Flument stack. Scheme of the fluvial stack in the Main River area, called the Main Formation. It consists of maximum six fluments: A, B, C, D1, D2, and E. Flument A, B, D1, D2, and E are fluments of vertically aggrading rivers. The small flument $C$ presents a lateral accretional river weathered by a Luvisol (red brown). Flument E embraces much slope debris supplied by a gully, cp. [45]. Each flument shows at least remnants of floodplain channel fills (green): A (reworked in B); B; D1 (reworked in D2); D2, and E (largely preserved). Above the back swamp of E (green) are silty-sandy deluvial coverbeds with two paleo-Luvisols (red brown) and the Luvisol at the surface. The Upper Triassic Burgsandstein is a quartz sandstone interfered with red shale. These shales, softer than the quartz sandstone, provide the possibility for lateral overlapping of the river deposits. (The overlapping extent is drawn here small owing to the page size. The scale of the heights is exaggerated.). 
It is remarkable that within the fluvial stack several fluments tend to overlap laterally, owing to the upward widening of the preformed valley that is used by the stack formation (Figure 8).

The fluvial stack of the Main River (Figure 7), dating to roughly 1-0.5 Ma [43], seems to grow up rather continuously. However, each break between the six preserved fluments shows a hiatus, indicating a standstill with soil formation and certain erosion. Concerning the glacial history, these hiatuses indicate the climatic change between glacial and interglacial periods, including the transitional period between both. Actually, during these transitional periods the bulk of erosion and a great deal of the accumulation happened.

On the other hand, there are often cases where fluvial stacks contain long-term hiatuses involving several glacial periods, as demonstrated later in Section 5.3.

\subsection{Flument Rows and, Respectively, Terrace Rows}

In the case of the missing incision of a river and continuing rhythmical formation of fluvial deposits, fluments and terraces can form a lateral row, called, respectively, row fluments and row terraces [9] (pp. 12, 28). There are a lot of papers dealing with row terraces, e.g., [6,16]. Herein, the terraces lie side by side, at least with its surfaces on the same level. Mostly, though, the flument bases also hold a similar level, which is the case among the Holocene floodplain fluments. Moreover, each of the younger fluments can form nested fluments within the terrace row (Figure 9). Separation of the individual fluments is possible morphologically by their floodplain edge channels, pedologically by their floodplain soils, and chronologically by their age. The amount of Holocene fluments within the terrace row at the valley bottom is rather constant in Central Europe [6,11].

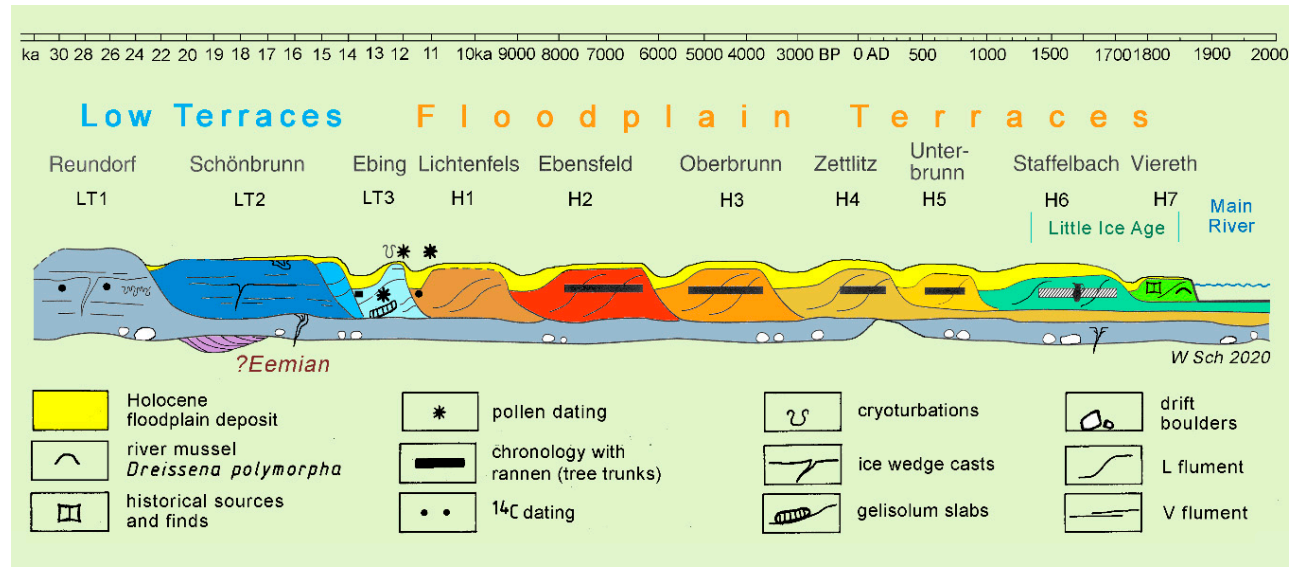

Figure 9. Terrace/flument row. Scheme along the Main River. From the Low Terrace 2 (LT 2) on, the river terraces of the valley floor form a terrace row. Occasionally, they get flooded (yellow), and therefore were called floodplain terraces. $\mathrm{H}=$ Holocene.

\section{Application of the Principles, and Special Problems}

\subsection{Fluvial Overlap and Stratigraphical Consequences}

Where flument flights, flument rows, and flument stacks occur together in one and the same fluvial edifice, the building of a stratigraphical system may get difficult. In the following, some examples are presented showing interaction of flument staircases, stacks, and rows:

\subsection{Lateral Overlap Confusing the Assignment of Terraces or Fluments}

A normal river deposit, called flument, is limited on top with a more or less even morphological terrace plain, an ortho-terrace (Figure 3). The way to becoming a terrace involves that the river plain and flument were again cut by the river to form a deeper-lying younger river plain, leaving aside parts of the older plain. 
If a river aggradation rises higher than the preceding river incision, the aggradation can overlap the incision form, provided that there is lateral space enough for overlapping (Figure 10a). Various overlapping stages are discussed by Blum \& Törnqvist [19].

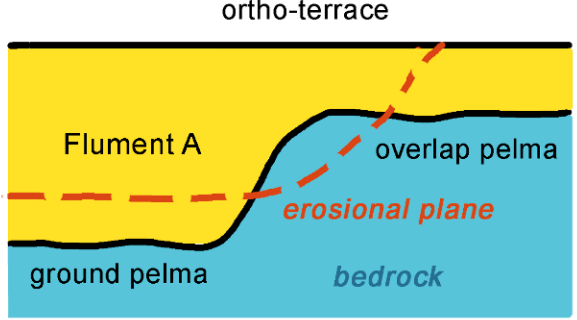

a

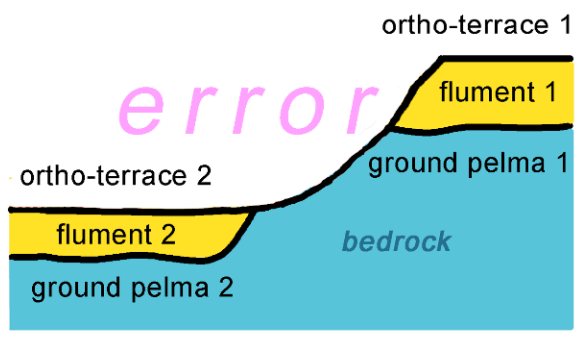

C

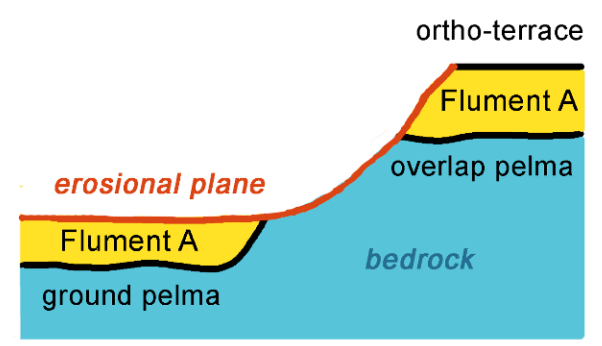

b

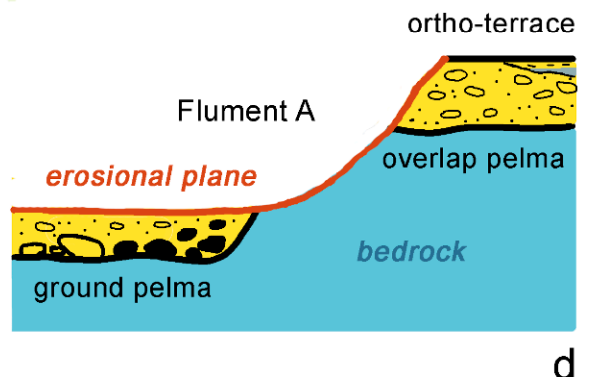

Figure 10. Flument overlap. (a) An overlapping flument causes two pelmas, a ground pelma and overlap pelma. (b) An erosional plane separates the two pelmas and the deeper part of the flument from its higher part. (c) A wrong interpretation of the separated fluments, actually presenting one flument. (d) An easier interpretation, using the flument structure in case both flument proportions show, respectively, the typical basal and upper facies of a flument.

The lateral overlap results in the formation of two different base levels (pelmas) - a lower pelma starting with the first emplacement of the flument, and a second and higher pelma starting with the lateral overlap of the river. Thus, one and the same flument has two base levels: the true ground pelma and the overlap pelma (Figure 10a). The overlap pelma lies higher than the true ground pelma of the river aggradation. This flument geometry may cause geological misinterpretation in the case of partial erosion (Figure 10b). The erosional plane cuts the Flument A in a way that both flument relics of Flument A appear to represent two different fluments of a stair case-an apparent older flument 1 and an apparent younger flument 2 (Figure 10c). Consequently, the overlap Flument A may give rise to counting the overlapping flument as two fluments, respectively, to consider the overlap pelma as an own ground pelma (Figure 10c). That means that constructing a flument flight of a valley may involve considering two pelmas as belonging to two fluments, unaware of the fact that the two pelmas could represent one flument only. Studying the case of Figure 10b, the fact that both fluments belong together could be underlined by the flument structure: the development of the deeper lying flument with basal facies (block layer [46] (Figure 8)), skeleton gravel, and the development of the higher lying flument with finer grained clastics and/or initial floodplain facies (Figure 10d).

\subsection{Lateral Overlap Confusing the Assignment of Individual Single Fluments}

The fluvial stack of the Main River, the Main Formation (Figure 7), comes up to 30-60 m thickness, $30 \mathrm{~m}$ upriver, $60 \mathrm{~m}$ downriver. It consists of at least six fluments. All fluments of the stack tend to overlap laterally. The overlap is shown schematically in Figure 8, and as a drawing true to life in Figure 11. 


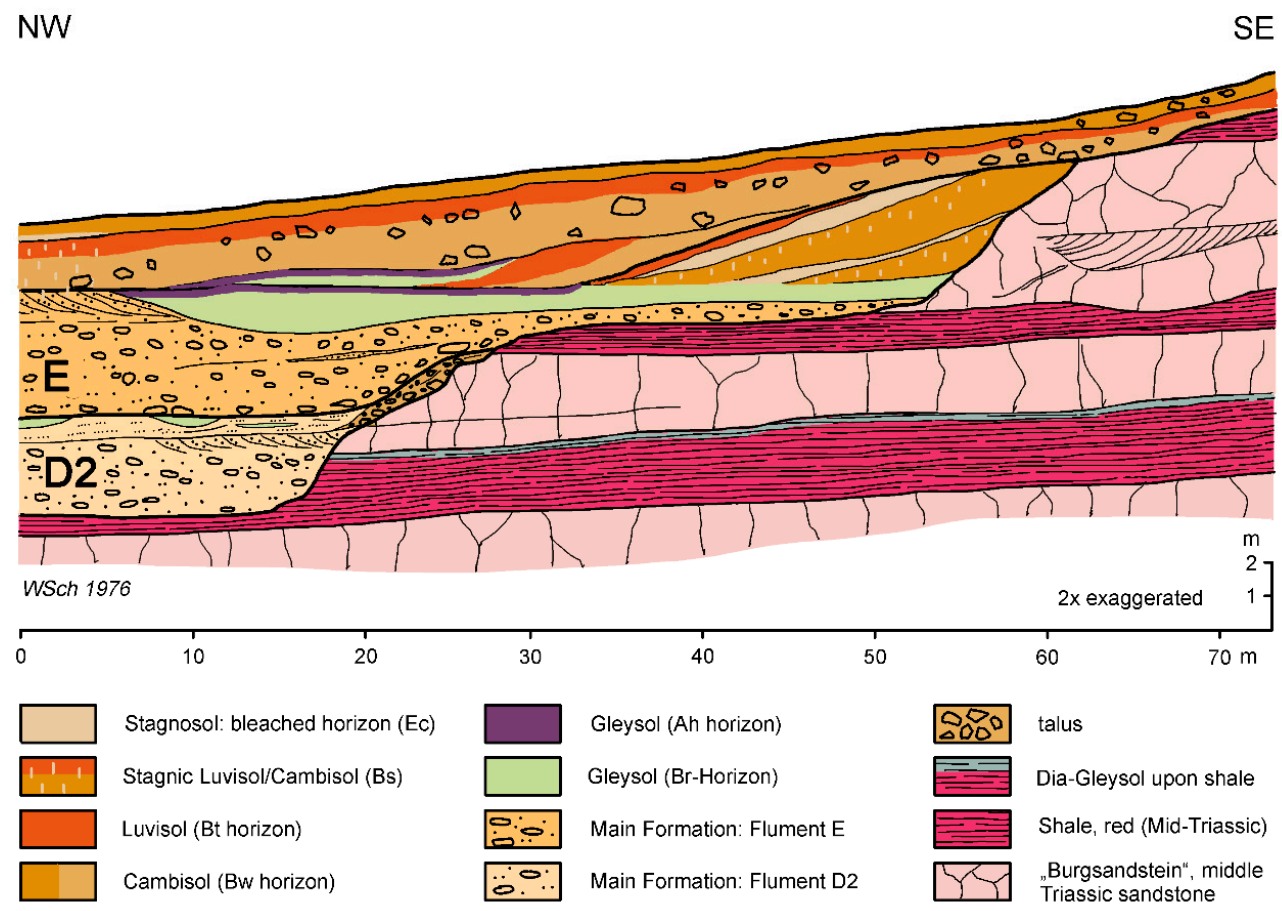

Figure 11. Flument overlap in the Main Formation. Flument D2 overlaps laterally more than 18 meters; Flument E overlaps $37 \mathrm{~m}$.

Figure 11 shows two overlaps: the lower overlap of flument D2, and the upper one of flument E. Both overlaps developed from lateral erosion, cp. [26], by the Main River against hard Triassic sandstone, using there, however, a weaker shale interlayer for prograding. If the river of this level would cross mere claystone, the progress of overlap would be easier and perhaps much more extended (Figure 12). Figure 12a is a theoretical figure demonstrating that the upper fluments of a flument stack may be able to deposit widely separated flument portions. Thus, as shown in Figure $12 b$, it is hardly possible to assign some fluments (green) as a flument of the stack (violet) or as an incision flument of the terrace flight (green) that follows after the pile-up of the fluments. It gets even more difficult to assign deposits of the opposite side of the valley (red in Figure 12b). The best possibility to assign those isolated fluments would be to date them directly. Dating by their lithological composition (e.g., pebble analysis, heavy mineral analysis) is useless, because the fluments of the flument flight (green) involve mostly reworked material from the flument stack (violet).
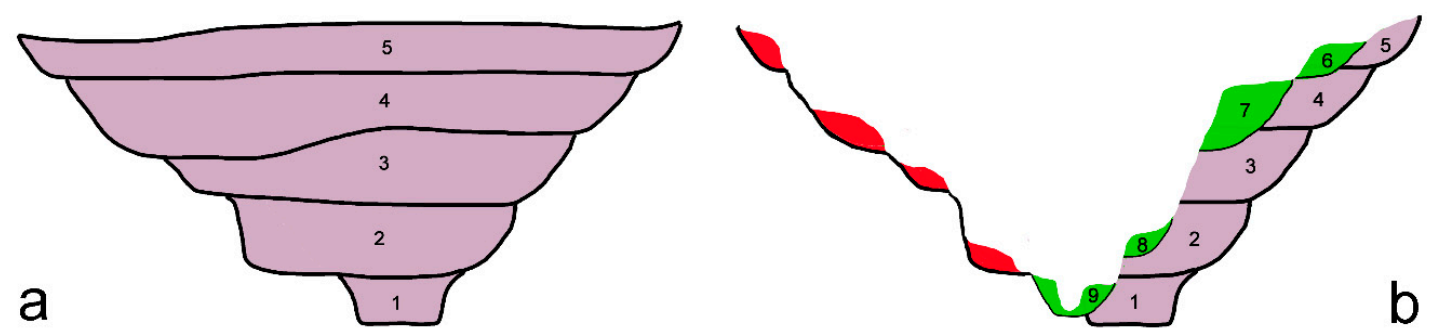

Figure 12. (a) A theoretical flument stack: 1 the oldest, 5 the youngest flument of the stack. (b) The stack has been eroded forming a flument flight (green) with four cut-in terraces (6-9) and leaving behind only remnants of the stack 1-5 (dark violet). On the left side of the valley occur isolated, so-called lost fluments (red), which are obviously unpaired, and the assignment of which is not clear, whether they belong to the stack (violet) or to the cut-in terrace flight (green) or represent additional fluments. 


\subsection{Lateral Overlap Owing to Shift of the Thalweg}

The Main River during its evolution changed its thalweg from east towards west. This was triggered by the onset of enhanced periglacial slope activity during the Middle Pleistocene.

At first, the river was close-joint running along the foot of the steep Jurassic escarpment of the Franconian Alb (Figure 1) for some hundred thousand years (Figure 13, eastern flank of the valley). Then, external feeding of periglacial debris from slopes and tributaries of the escarpment increased so eminently that the river was gradually pushed to the western side. This side was bound by Lower Jurassic clayey deposits. Thus, the Main River easily undermined the western side by gradual shifting of its thalweg toward the west.

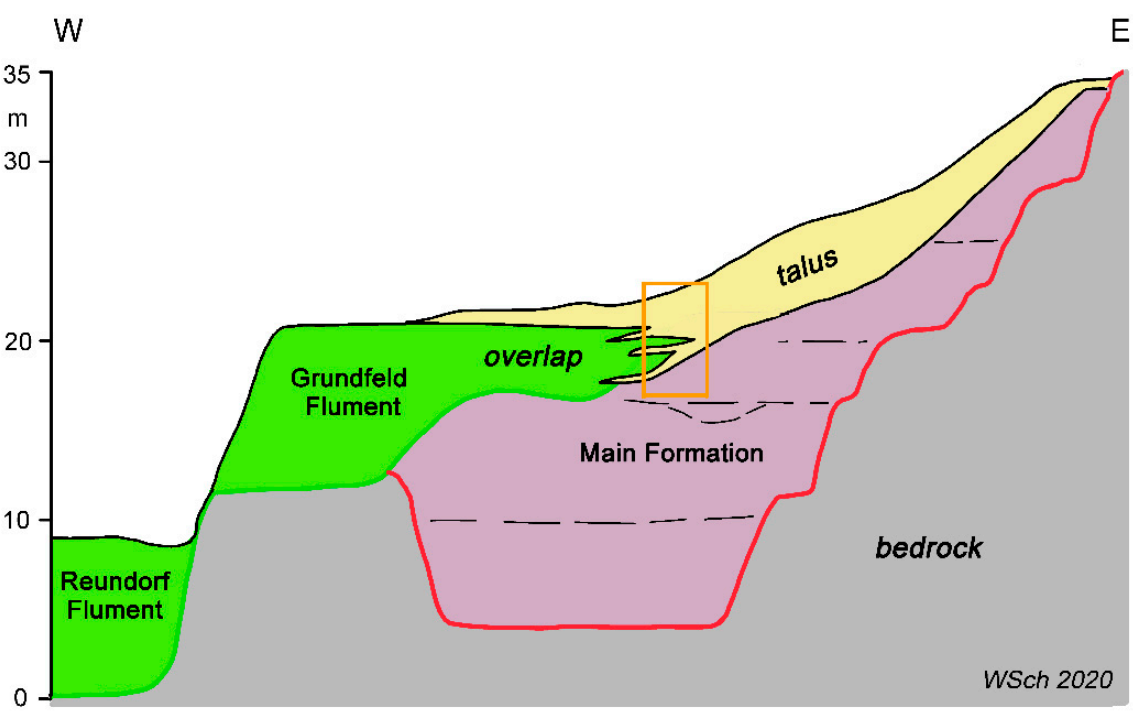

Figure 13. Scheme of the valley's shift from east to west: Red line: Pelma of the eastern valley filled by the Main Formation. Green: Fluments of the western valley with overlap of the Grundfeld Flument over the truncated eastern valley filled by the Main Formation. Brown rectangle: Detail of the overlap situation in the Grundfeld gravel pit in Figure 14.

By the shift of the thalweg, the river ceased downworking into the loose gravel of the Main Formation, leaving a socle of the Main Formation of $1 \mathrm{~km}$ in width and more than $10 \mathrm{~m}$ in thickness. In its new thalweg, it cut vertically deeper into a clayey bedrock. Now, nestled in its new valley bed, the river in places filled up its aggradation somewhat higher than the truncated Main Formation, overlapping the truncated surface of its old thalweg. Figure 13 as scheme, and Figure 14 as drawing true to life, show the overlapping Grundfeld Flument over the socle parts of the Main Formation prior to being covered by deluvial slope debris. Thus, two morphological terraces lie in tight superposition in the eastern river bed: the truncation terrace of the Main Formation and the Grundfeld Terrace upon it as a thin overlap flument. Certainly, it is a rare combination: an overlap flument upon a cut-in-fill terrace. Coming back to Section 4.2, the Grundfeld flument (assigned to the Marine Isotopic Stage 8) here forms a stack together with the Main Formation below, presenting an unconformity of roughly 300 ka years between them.

A comment on Figure 14: The Grundfeld Flument that overlaps here with its uppermost part consists of three subunits (1-3). All of them merge from upslope local gravel (triangles) downslope into Main gravel (green, gravel = pebble signature, sand $=$ dots). The three subunits are separated by soil horizons (red colored, see legend). The subunits 2 and 3 could present substages of the Marine Isotopic Stage (MIS) 7. 


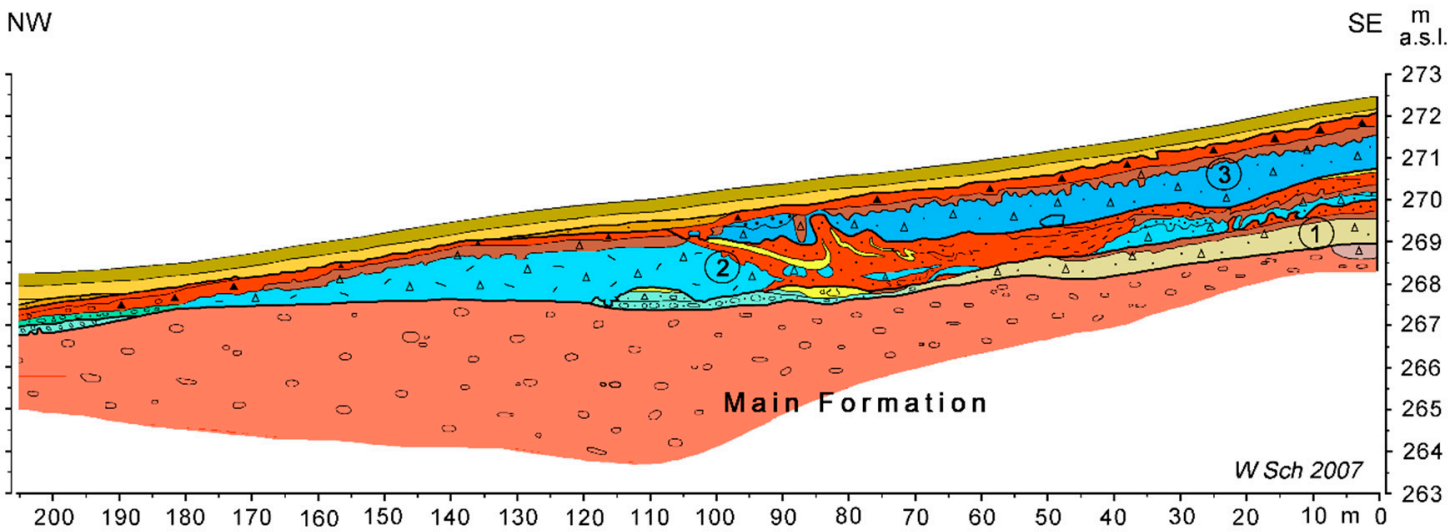

\begin{tabular}{|c|c|c|}
\hline Surficial humus & & $\begin{array}{l}\text { Bt or Bw horizon } \\
\text { reddish brown or brown }\end{array}$ \\
\hline $\begin{array}{l}\text { Loess layer, carbonaceous } \\
\text { last glacial }\end{array}$ & & $\begin{array}{l}\text { Bw+C horizon above } \\
\text { carbonaceous local gravel }\end{array}$ \\
\hline $\begin{array}{l}\text { Loam, non-carbonaceous } \\
\text { penultimate glacial }\end{array}$ & \begin{tabular}{|l|l|}
$\Delta$ & $\boldsymbol{\Lambda}_{\boldsymbol{\Delta}}$ \\
\end{tabular} & Local gravel, carbonaceous / non-carbonaceous \\
\hline $\begin{array}{l}\text { Floodplain channel deposit } \\
\text { silty, sandy, gleyey }\end{array}$ & 0.00 & Gravel of the Main River, non-carbonaceous \\
\hline $\begin{array}{l}\text { Grundfeld Flument unit } 1 \\
\text { mainly local sediments }\end{array}$ & & $\begin{array}{l}\text { Grundfeld Flument unit } 3 \\
\text { mainly local sediments }\end{array}$ \\
\hline $\begin{array}{l}\text { Grundfeld Flument unit } 2 \\
\text { mainly local sediments }\end{array}$ & 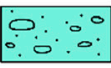 & $\begin{array}{l}\text { Grundfeld Flument, units } 1-3 \text { : } \\
\text { Main River sediments }\end{array}$ \\
\hline
\end{tabular}

Figure 14. Grundfeld-Strassäcker gravel pit. Location: see quadrangle in Figure 13. Overlap of the Grundfeld Flument, with subunits 1-3, upon the truncated Main Formation. The colors of subunits 1-3 vary in order to contrast the three subunits, and local gravel and Main gravel (green) within the subunits.

\section{Flument Inventory of the Valley Bottom and Its Underground}

\subsection{Terrace Patterns of the Valley Bottom}

The lowest surface of the valley is called the valley bottom. The valley fill beneath is called the valley underground. The terrace pattern (Figure 15) is the configuration of the nowadays preserved fluments of the valley bottom. The four main terrace patterns (surface patterns) are recognized as occurring frequently along most rivers in Central Europe and other areas, e.g., [3,47-49]. Naturally, those patterns also existed during all former interglacials. However, these former interglacial periods are preserved by their fluments only and not by their terraces.

\subsection{Terrace Texture of the Valley Underground}

The valley underground is a treasure full of secrets. Unravelling them is difficult because of its frequent position under groundwater. In rare cases, construction pits allow full insight. On the Upper Main River sometimes the gravel pits were pumped out to gain the gravel, nearly completely in contrast to exploitation of gravel and sand from those pits filled with ground water.

Within areas of minor tectonical uplift, the valley underground consists of the following units (Figures 9 and 16): the Holocene fluments are presented as row terraces. Sometimes, Late Pleistocene fluments are adjoining. Underneath occur socles of Late Pleistocene fluments down to the pelma.

The terraces of the valley bottom can form step terraces, form row terraces, form stack fluments with overlap, or they can present nested terraces (Figure 16). Mostly a mixture of all occurs. The term step Terrace (Figure 16a) refers to a flight of steps at the surface; additionally, the bases are often stepped. The term row Terraces (Figure 16b) refers to a level row of different terraces at the surface; additionally, 
the bases may be level among themselves, or they have a nested texture, as visible in Figure 9 with the H5 and H6 terraces. Stack Fluments (Figure 16c) refer to a stacked texture, the uppermost flument of which forms a \pm level surface; the bases of the fluments underneath may be level, incised, or have a nested or other texture. In contrast to these foregoing textures, a nested texture (Figure 16d) refers to the base of the flument and highlights that the flument base lies higher than the base of the flument underneath; the surfaces of a nested texture may form a terrace row, a stepped terrace flight (Figure 16d), or a level surface (Figure 16c).

The reason for the different textures mostly is either tectonic movements or alterations of the river regime during the glacial-interglacial changes.

In areas of stronger uplift, the fluments form step terraces, where the Holocene terraces form the pelma of the valley fill, e.g., on the Danube River [6] (p. 46). In contrast, areas of subsidence present textures much more differentiated and richer in the amount of fluments above the pelma, e.g., molasse basins [50], or in graben structures. In the Upper Rhine Graben (Figure 1), the thickness of the Quaternary comes up to $500 \mathrm{~m}$ subdivided by many lithofacies units [44]. Additionally, the Pliocene underneath comes up to $500 \mathrm{~m}$ [51].

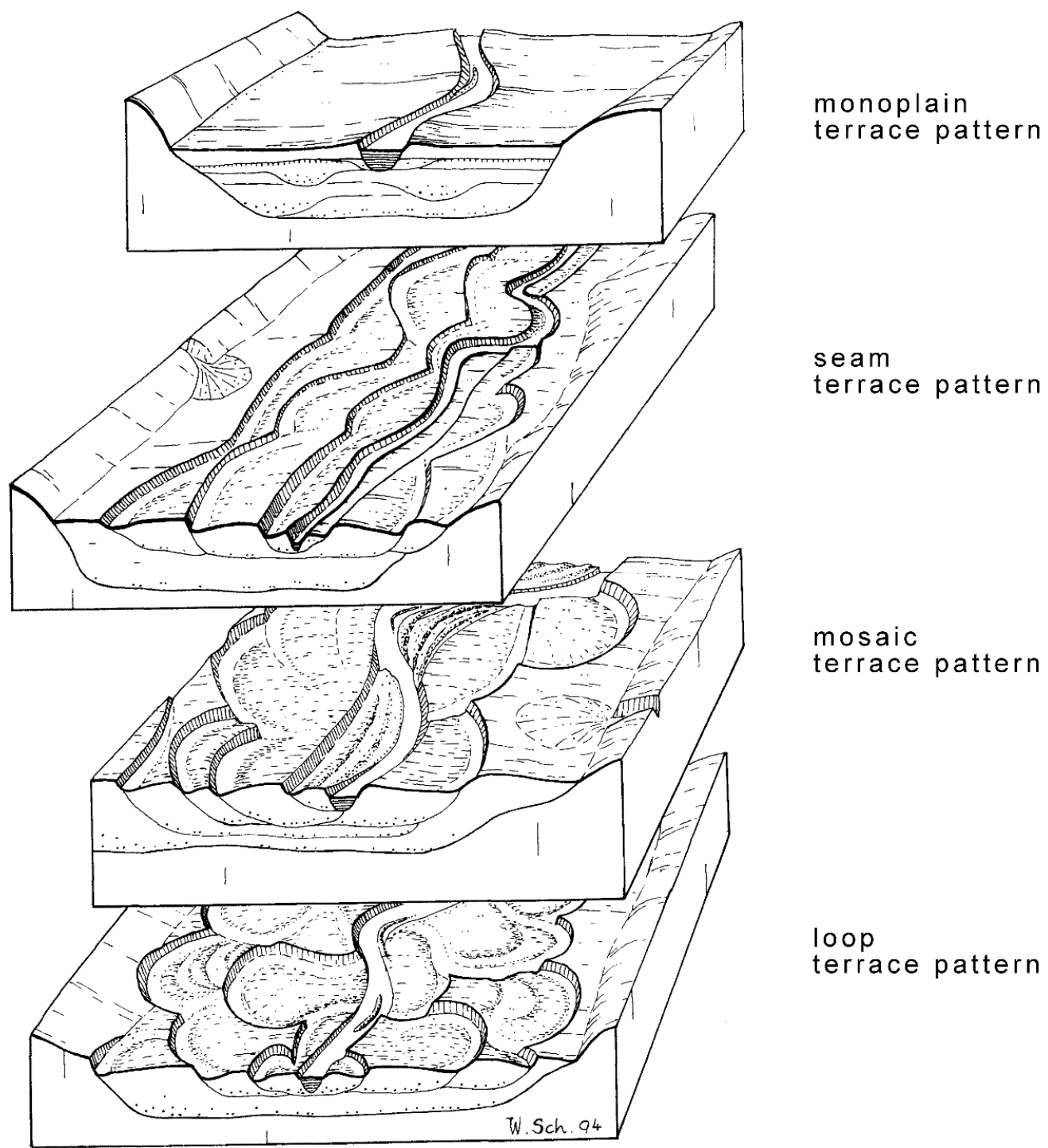

Figure 15. Terrace patterns in the valley bottom. 


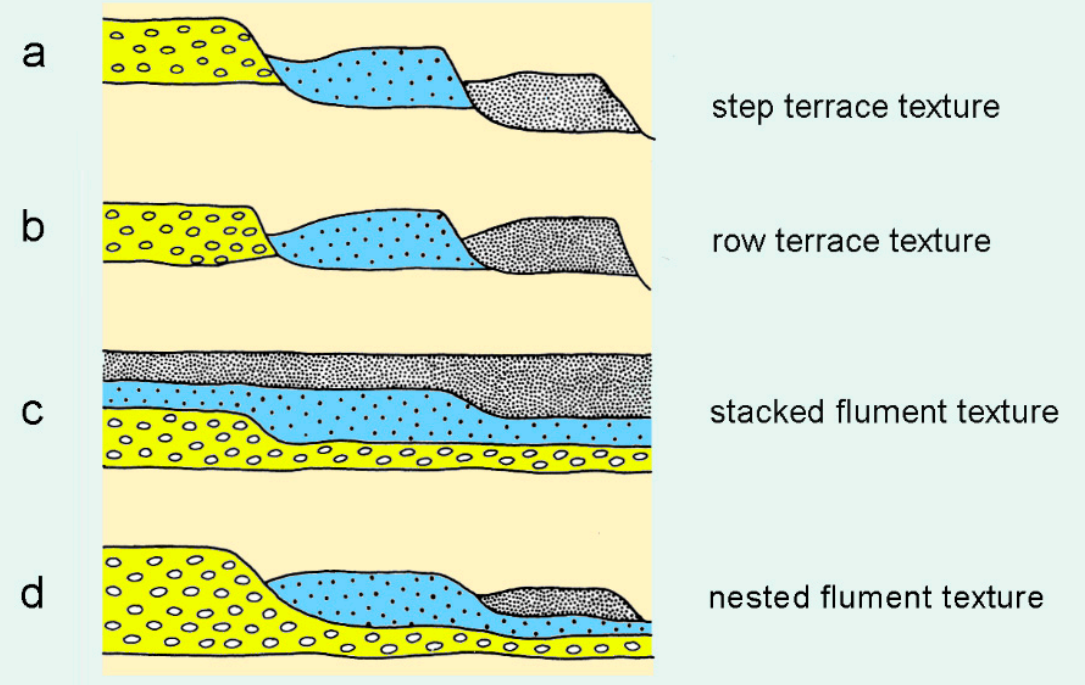

Figure 16. Principal flument textures of minor tectonical movements of the valley bottom in Central Europe.

\subsubsection{Varied Relief Sculpture of the Pelma in the Valley Underground}

Normally, the sculpture of the pelma or strath varies from even to wavy. Wegmann et al. (Apennines) [52] and Burbank et al. (USA) [26] record of altitude variation of the strath/pelma up to $3 \mathrm{~m}$. Sometimes there occur scours from locally older erosional events, as shown in Figure 17 by the Flument 1; it is a presumably MIS 5 erosion.

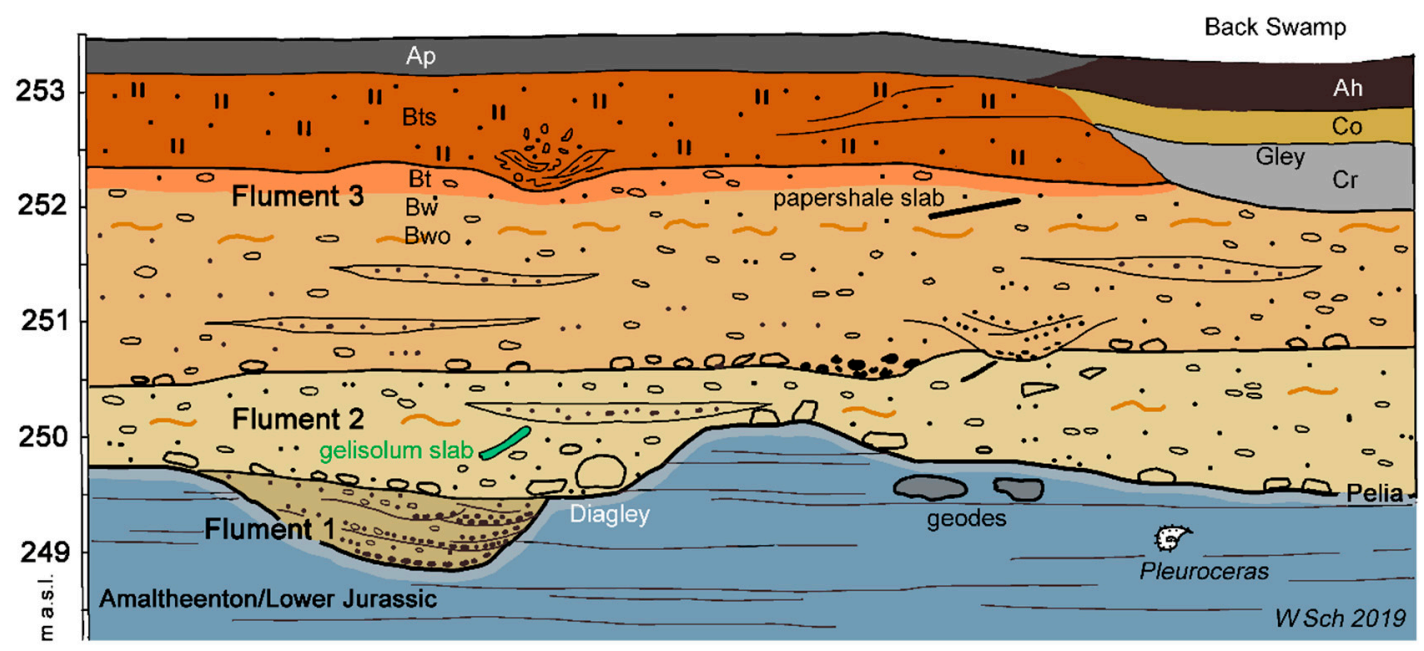

Figure 17. Three stacked fluments in the valley underground below a Last Glacial terrace. Sketch of the construction pit of the sewage Unterzettlitz close to Bad Staffelstein/Bavaria (Location in Figure 1). Length about $100 \mathrm{~m}$. Height enlarged about eight times. Flument 1 shows a warm-climate L-flument (presumably MIS 5). Flument 2 presents the Reundorf Flument (70-c. 30-20 ka). Flument 3 represents a late Pleniglacial flument (20-11.7 ka) (Schönbrunn or Ebing Flument).

Moreover, hillocks of the pelma occur as shown in Figure 8 below the Zettlitz Terrace. The hillock rises so high that the basal erosion of the Zettlitz Flument could completely scour away the socle of the Reundorf Flument. In rare cases-if harder rocks adjoin much weaker ones-such hillocks tower above the valley terraces forming islands in the valley bottom. 


\subsubsection{Scouring Out the Valley Underground}

In the Upper Main area, where the water is pumped out for excavation of gravel, the whole structure of the valley underground can be studied.

Normally, the pelma of the valley underground is formed by the Late Pleistocene deposits, in Figure 9 the older parts of the Reundorf Flument. Where the Reundorf Terrace itself is cut by younger fluments, these younger fluments show nested texture (Figure 9) in a way that the older parts of the Reundorf flument remain always as socle below the younger fluments. Such an example is shown by the Zettlitz Flument that overlies the socle of the Reundorf Flument.

In the case of Figure 18, the older part of the Reundorf flument encompasses at its base remnants of mammoth tusks with a ${ }^{14} \mathrm{C}$ age of $23.415 \pm 475$ a BP, roughly calibrated to $28 \mathrm{ka}$ BP. Above occurs a layer of fines with drop soils, and even higher follow the fine grained interstadial Abtswiesen Beds [53] (p. 51) with a thin peat layer dated to $20.525 \pm 410$ a BP, calibrated to roughly $25 \mathrm{ka}$ BP. These Abtswiesen Beds cut unconformably ice wedge casts (Figure 19) that extend down through the pelma into the bedrock - here represented by Upper Triassic red shales called Feuerletten (fire shale). In places, between the basal Reundorf Flument and the Zettlitz Flument flument remnants may be left of older Holocene age dated by wood.

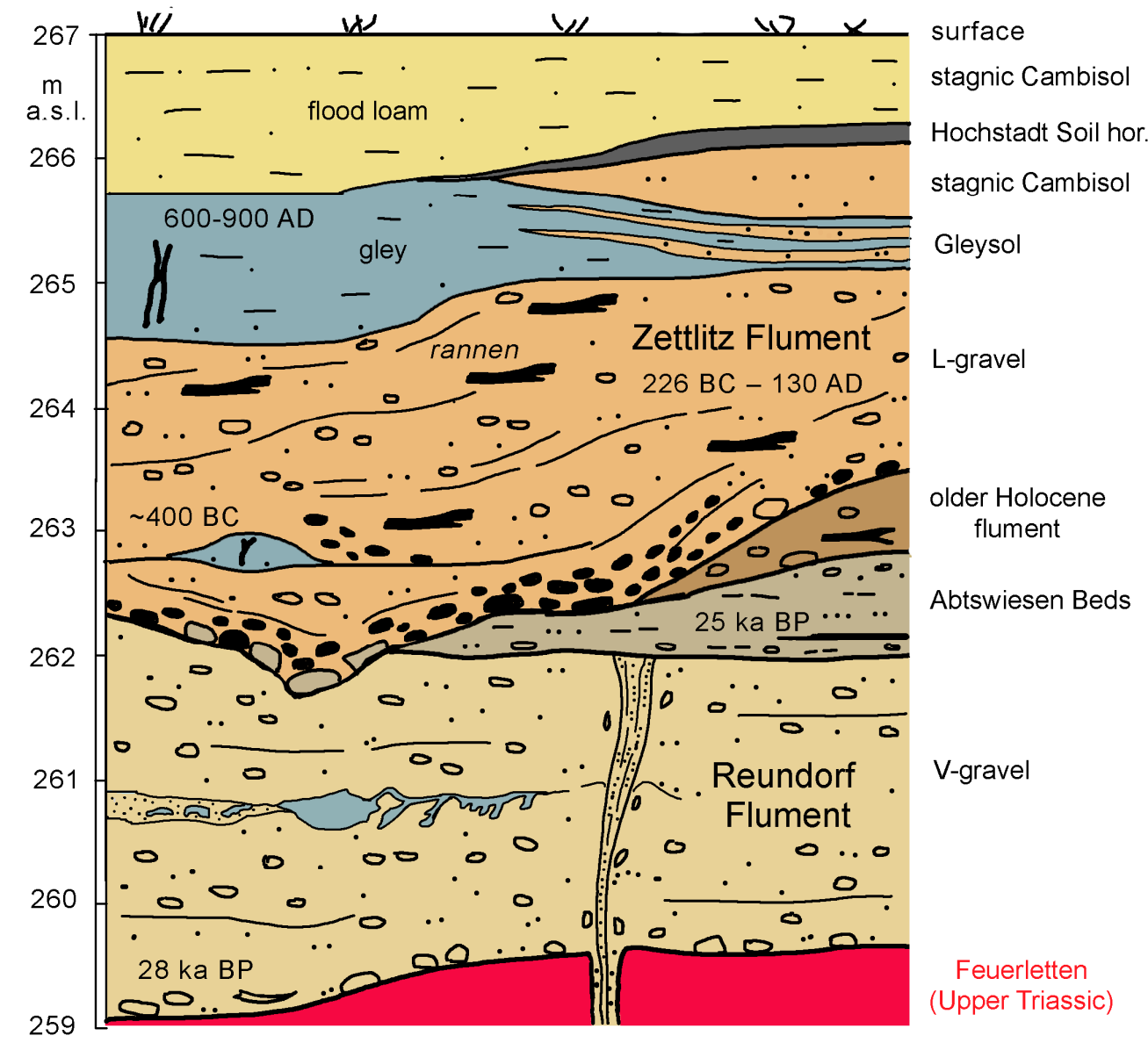

Figure 18. Stacked fluments in the valley underground below a Holocene terrace. Sketch of an area of several gravel pits in the Zettlitz Terrace in Lichtenfels-Trieb/Bavaria. The Reundorf Flument is preserved by its socle containing the interstadial Abtswiesen Beds. These Pleniglacial deposits are unconformably overlain by the roughly 2000 years old Zettlitz Flument that is completed by the Early Medieval Hochstadt Soil horizon [54] (p. 52), since then overlain by younger flood deposits. 


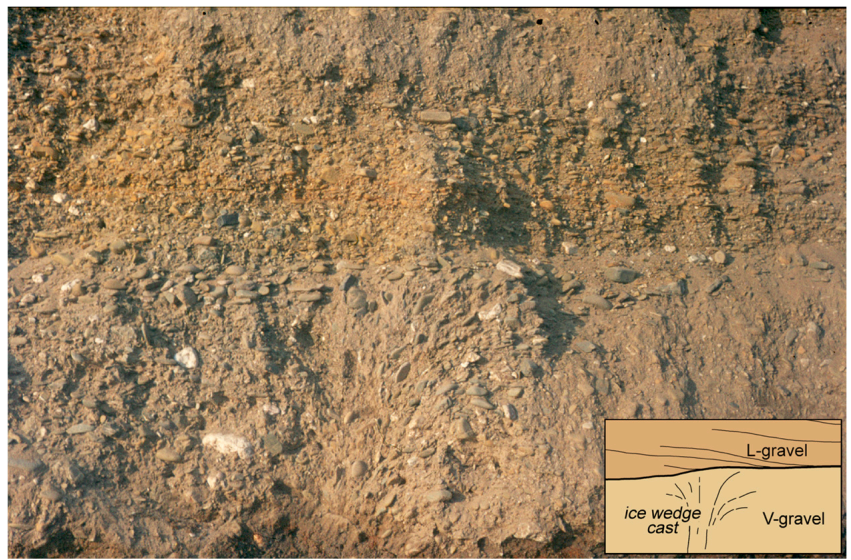

Figure 19. The lateral accretion gravel (L-gravel) of the Holocene Zettlitz Flument overlies unconformably the vertical aggradation gravel (V-gravel) of the Late Pleistocene Reundorf Flument that includes an ice wedge cast (Photo: W. Schirmer, 12 October 1972).

\subsubsection{Holocene Fluments and Terrace Row}

The differentiation of the Holocene flument row $[9,11]$ is possible by:

1. mapping the morphological terrace row (see Figure 15), starting with mapping from aerial photos, followed by field mapping and (hand)coring at particular points;

2. identification of their surface soils, best to do by small pits, less good by corings. These soils vary from older to younger terraces from strongly or mature soils to the incipient soil of the youngest terrace. In the temperate climate, the soil catena ranges from Luvisol over Cambisol to Leptosol. This soil development passes off quicker the lower the carbonate content of the floodplain deposits. Thus, in river areas with high carbonate content (e.g., Alpine-connected rivers), the differentiation of floodplain soils allows optimal differentiation of the individual floodplain terraces [11] (p. 37);

3. gathering datable material within the fluments: wood remnants, especially rannen (tree trunks), pollen, etc. Remarkable are rannen (Figure 20) that give exact dendrochronological death times for their imbedding moment. These death times testify to the regularly flooding that destroys the riverine forest and accumulates the Zettlitz flument (H4 in Figure 9). As in all seven Holocene fluments and terraces, this Zettlitz flument is distributed in all valleys of Central Europe, indicating enhanced fluvial activity. On the Main River it dates from 226 BC to 130 AD [55].

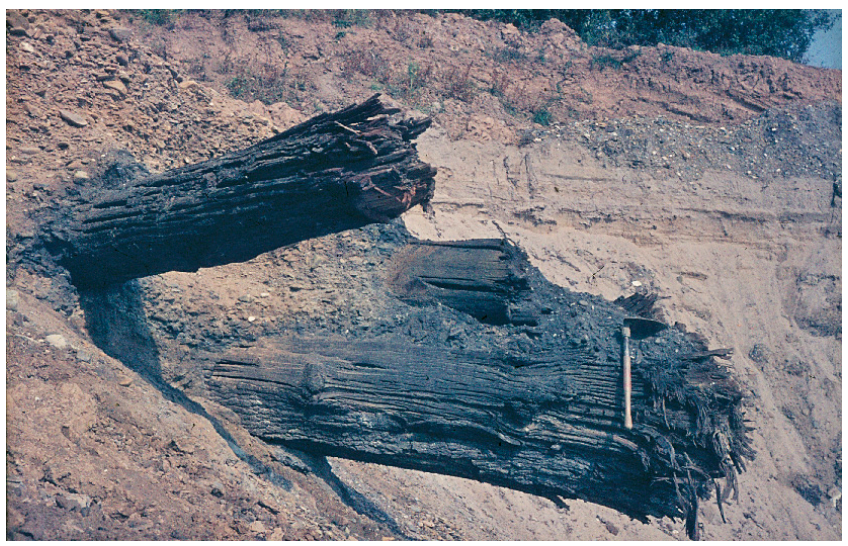

Figure 20. Rannen (fossil tree trunks) in the Zettlitz Flument (226 BC-130 AD) in a gravel pit at Lichtenfels-Trieb/Bavaria. Stratigraphical position see Figure 18 (Photo: W. Schirmer 19 September 1971). 


\section{Discussion}

The discussion focuses terms and processes of the valley inventory in comparison to other usage (Figure 21).

\section{Erosional forms}

a

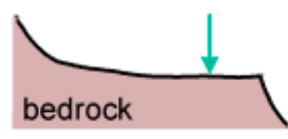

b

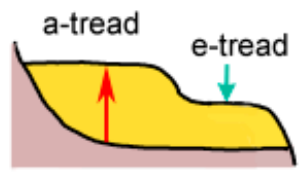

C

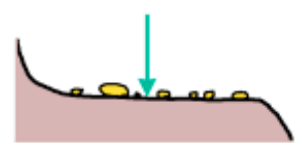

fluvial rock(-cut) terrace

cut-in terrace in bedrock erosional terrace in bedrock strath terrace without flument

cut-in-fill terrace erosional terrace

a-tread $=$ aggradational tread e-tread $=$ erosional tread

pelma terrace nested flument

\section{overlap flument \\ causing stacked flument}

Figure 21. Terraces and fluments discussed in this paper. (a) Fluvial rock terrace; (b) Cut-in-fill terrace; (c) Pelma terrace; (d) Cut-in flument; (e) Nested flument; (f) Stacked flument.

\subsection{Definitions of Fluvial Terms Used in this Paper}

\subsubsection{Fluvial Erosional Forms: (Morphological) Terraces}

Cut-in terrace. Synonyms: Stream-cut terrace, e.g., [36], erosional terrace, degradational terrace (e.g., [26] (p. 32)). Using "erosional" and "degradational terrace" should mark whether the degradation was formed fluvially or by general wearing down. Most common erosional terrace type.

Special Conditions:

Erosion host is pure bedrock:

a. Fluvial rock terrace or Fluvial rock-cut terrace: A terrace within the bedrock, softer or harder, without fluvial deposits. Sometimes difficult to decide whether it originates from fluvial erosion, or from another erosional process in the context of wearing down, or a mixture of both. 
Comparison: Corresponds to Rock terrace sensu Bucher [36] and to strath terrace (pars) without any flument (alluvial cover) e.g., [40]. See Section 7.2.

Erosion host is pure flument (see below 2.):

b. Cut-in-fill terrace, e.g., [17,56]. Synonym: Fill-cut terrace (e.g., Bull [18] (p. 8)). Comment: Erosional terraces in fluments should be checked carefully whether they actually are not cut-in fluments. Compare: (e.g., Hargitai [57], 2240). Remark on Figure 2b in Hargitai: It should not have a line separating the fill-cut flument ("Terrace") from the hosting flument; [56].

Erosion host is flument plus bedrock:

c. Pelma terrace: A terrace cut into the flument base almost down to the pelma carrying an eluvial relictic flument litter. This relictic flument litter may be developed by fluvial degradation and/or by denudational erosion.

\subsubsection{Fluvial Depositional Forms: Fluments}

V-flument: Vertically aggradational flument. Most common flument type of the braided rivers.

L-flument: Laterally accretional flument. Most common flument type of meandering rivers.

Both types of flument terminate above with a flument terrace that changes from the well-preserved ortho-terrace by erosion or denudation to the oblique dia-terrace and eventually to the pelma-terrace that traces the pelma with last relics of the eluvial flument.

Compare: "fill terrace" (e.g., Bucher [18,36,57]), aggradational terrace or constructional terrace e.g., [26]: they correspond to V- or L-flument plus their terrace (tread).

\subsubsection{Fluvial Forms with Cyclic Alternating Erosion and Deposition}

d. Cut-in flument: A flument cut in older fluments or/and bedrock. Most common flument texture in valleys.

e. Nested flument, fill-in flument: A normal flument inset in an older flument. Actually, it is an incised flument within a small flument staircase, with its tread below that of the host flument and its base above the base of the host flument.

Compare: "Nested fill terrace", e.g., [17], or "Cut-and-fill terrace" that correspond to nested flument.

f. Stacked flument: Overlapping flument and/or superimposed flument (Figure 8). Actually, a superimposed flument always should start with overlapping.

\subsection{Comment to Strath and Strath Terrace}

It is not easy to place the term strath terrace in the category of the other terraces or fluments. Therefore, the following remarks apply to this term:

Its definition has been altered several times since Bucher (1932) [36]. "The controls on the formation of bedrock straths are still debated" (Burbank \& Anderson 2012 [26], p.33).

Bucher's strath is a flat, elongated, and especially wide valley surface with both degradational stream portions and marginally non-fluvial, probably weathering portions. He neither mentions the position of the surface in bedrock nor occurrence of stream deposits.

However, both bedrock surface and stream deposits were coupled with Bucher's term strath later $[21,25,29,37,39,40,58]$. The following facts were developed from Bucher's scanty statements:

1. The contact between bedrock and overlying deposits of any kind is called strath. The bedrock forming the bed of a contemporary channel is called active strath (Wohl [59] p. 1).

2. The name "strath terrace" is given to any terrace involving the strath: both to an abandoned surface of the bedrock as ledge in a fluvial context, and to a strath covered with fluvial deposits, sometimes degradational, sometimes aggradational, sometimes very thin, sometimes up to $5 \mathrm{~m}$ in thickness [57]. In the end, terraces and fluments of all those types were called "strath terrace". 
They occur within a staircase, sitting on bedrock that is bare or covered by aggradational deposits, e.g., $[18,52]$.

Howard's fillstrath terrace $[21,60]$ (see 7.2), far beyond these definitions, was meanwhile dropped. Comment:

Whether a flument is cut into the bedrock or not is not important for the flument. Fluments may have an underlay that merges from bedrock into older fluments (Figure 11). The kind of underlay of a flument should not affect the type and name of the flument (plus its morphological terrace). A classification of fluments should characterize the fluments themselves and their context in the fluvial valley edifice. Consequently, strath terraces cannot be grouped and compared with the other mentioned "terraces" or fluments. The major importance of strath terraces is to determine incision rates of the stream [29] (p.1131\}, [40,52,61].

Hancock \& Andersen [29] (p. 1131) state: "The beveled strath and thin alluvial cover distinguish strath from fill terraces, which have no underlying bedrock platform and can be many tens of meters thick".

Comment:

1. For the fluvial beveling of strath by an eroding stream, the thickness of the overlying flument is unimportant. The thin alluvial cover on strath terraces is manifold stated [18,22]. It is a consequence of the deeply eroded (degraded) fill of the highest elevated fluments of a terrace flight. The Main Formation of $30 \mathrm{~m}$ thickness as stack of fluments ("fill terrace") rests on a strath/ground pelma.

2. Each flument ("fill terrace"), of course, sits on underlying bedrock. In the case of a flument stack, it is only the lowermost flument that rests on bedrock.

A strath terrace with sparse relics of an eluvial flument corresponds to the ground-pelma terrace (Figure 5). A strath terrace with thinner or thicker aggradational cover is a normal flument terrace. The use of the name "strath terrace" for a flument overlying the bedrock is a frequently applied case in American literature. Yet, Easterbrook [17] does not involve it into his system of terraces at all.

Thus, "strath terrace" is not a term characterizing a flument itself, but characterizing the spatial position of a fluvial phenomenon in regard to the bedrock within a valley $[40,52]$. The only common feature of strath terrace and flument terrace is that both are cut-in terraces.

\subsection{Glossary of Fluvial Terms Used in the Paper}

See Table S1 in supplementary file. It includes the term Main Formation [62].

\section{Conclusions}

The edifice of fluvial deposits exhibits a large variety of forms and textures, in addition to a large variety of preservation conditions. The older the fluments are, the more relictic is their architecture.

An important point of vertical subdivision is the recognition of unconformities between different fluments. For this, it is essential to study good and large outcrops and to follow their excavation progress over long periods of time.

The principles mentioned first in Section 3 should be applicable to all fluvial investigations, even to pre-Neozoic ones [63]. The knowledge of the inner structure of a flument is important for the reconstruction of fluviatile series by flument remnants. Likewise, an ortho-terrace can be reconstructed by knowledge of the flument structure. By building a flument flight, smaller or larger terrace stacks can be an obstacle. Flument overlap is certainly a frequent case, but is difficult to recognize. A special case is the shift of a valley. It may highly confuse the construction of a terrace flight, as shown in Section 5.3. The occurrence of a flument flight side by side to an earlier fluvial stack is surely a rare case. However, in smaller sections or during shorter periods, it may happen in many valleys. The flument architecture of the valley underground varies depending on the local tectonical situation. The cases presented here, including some variations, are frequent in many valley undergrounds all over the world. 
Supplementary Materials: The following are available online at http://www.mdpi.com/2076-3263/10/12/501/s1, Table S1: Glossary of fluvial terms used in the paper.

Funding: This research received no external funding.

Acknowledgments: Thanks to the two unknown reviewers for their valuable advice and constructive criticism. For providing literature, I thank Gudrun Klein, FAU Erlangen. I am grateful for the editorial improvement of the English style.

Conflicts of Interest: The author declares no conflict of interest.

\section{References}

1. van den Berg, M.W. Fluvial Sequences of the Maas-A 10 Ma Record of Neotectonics and Climate Change at Various Time-Scales. Master's Thesis, University of Wageningen, Wageningen, The Netherlands, 1995.

2. Bibus, E. Zur Relief-, Boden- und Sedimententwicklung am Unteren Mittelrhein. Frankfurter Geowissenschaftliche Arbeiten 1980, D1, 295.

3. Miall, A.D. The Geology of Fluvial Deposits; Springer: Berlin, Germany, 1996; p. XVI + 582.

4. Boenigk, W.; Frechen, M. The Pliocene and Quaternary fluvial archives of the Rhine system. Quat. Sci. Rev. 2006, 25, 550-574. [CrossRef]

5. Keller, T.; Radtke, G. Quartäre (Mosbach-Sande) und kalktertiäre Ablagerungen im NE Mainzer Becken (Exkursion L am 14. April 2007). Jahresber. Mitt. Oberrh. Geol. Ver. 2007, 89, 307-333. [CrossRef]

6. Schellmann, G. Neue Befunde zur Verbreitung, geologischen Lagerung und Altersstellung der würmzeitlichen (NT 1 bis NT 3) und holozänen (H 1 bis H 7) Terrassen im Donautal zwischen Regensburg und Bogen. Bamb. Geogr. Schr. 2010, 24, 1-77.

7. Cordier, S. Archive Sédimentaire et Paléoenvironments Pléistocènes et Holocènes: De la Géochronologie Aux Forcages (Basin de la Moselle, Méditerranée Orientale, Madagascar). Habilitation Thesis, Université de Lorraine, Lorraine, France, 2015. Volume 367. p. 397.

8. Preuss, J.; Burger, D.; Siegler, F. Die Obere Terrassengruppe im Oberen Mittelrheintal-Orte neuer Beobachtungen und Interpretationen (Exkursion E am 25. April 2019). Jahresber. Mitt. Oberrh. Geol. Ver. 2019, 101, 117-149.

9. Schirmer, W. Die Talentwicklung an Main und Regnitz seit dem Hochwürm. Geol. Jahrb. A 1983, 71, 11-43.

10. Schirmer, W. Breaks within the Late Quaternary river development of Middle Europe. Aardkd. Meded. 1991, $6,115-120$.

11. Schirmer, W. Valley bottoms in the late Quaternary. Z. Geomorphol. 1995, 100, 27-51.

12. Schirmer, W. Rhein Traverse. In Quaternary Field Trips in Central Europe; Schirmer, W., Ed.; Pfeil: München, Germany, 1995; Volume 1, pp. 475-558.

13. Schirmer, W. Der Marktzeulner Paläomäander der Main-Formation. Jahresber. Mitt. Oberrh. Geol. Ver. 2013, 95, 391-420.

14. Schirmer, W. Flussterrasse und Flument/River terrace and flument. Geol. Bl. Nordostbayern 2019, 69, 131-136.

15. Schirmer, W. Pelma erosion and climate. Erlanger Beitr. Petrogr. Mineral. 2019, 29, 67-74.

16. Brakenridge, G.R. Rate estimates for lateral bedrock erosion based on radiocarbon ages, Duck River, Tennessee. Geology 1985, 13, 111-114. [CrossRef]

17. Easterbrook, D.J. Surface Processes and Landforms, 2nd ed.; Prentice Hall: Upper Saddle River, NJ, USA, 1999; 546p.

18. Bull, W.B. Geomorphic Responses to Climate Change; Oxford University Press: Oxford, UK, 1991; 326p.

19. Blum, M.D.; Törnqvist, T.E. Fluvial responses to climate and sea-level change: A review and look forward. Sedimentlogy 2000, 47 (Suppl. S1), 2-48. [CrossRef]

20. Soergel, W. Die Diluvialen Terrassen der Ilm und Ihre Bedeutung für Die Gliederung des Eiszeitalters; Gustav Fischer: Jena, Germany, 1924; 79p.

21. Howard, A.D. Numerical systems of terrace nomenclature: A critique. J. Geol. 1959, 67, 239-243. [CrossRef]

22. Howard, A.D.; Fairbridge, R.W.; Quinn, J.H. Terraces, Fluvial-Introduction. In Geomorphology. Encyclopedia of Earth Science; Springer: Berlin/Heidelberg, Germany, 1968. [CrossRef]

23. Soergel, W. Die Ursachen der diluvialen Aufschotterung und Erosion; Borntraeger: Berlin, Germany, 1921; 74p.

24. Schumm, S.A.; Mosley, M.P.; Weaver, W.E. Experimental Fluvial Geomorphology; John Wiley: New York, NY, USA, 1987; 413p. 
25. Bull, W.B. Stream-terrace genesis: Implications for soil development. Geomorphology 1990, 3, 351-367. [CrossRef]

26. Burbank, D.W.; Anderson, R.S. Tectonic Geomorphology; Wiley-Blackwell: Hoboken, NJ, USA, 2012; 454p.

27. Schanz, S.A.; Montgommery, D.R.; Collins, B.D. Anthropogenic strath terrace formation caused by reduced sediment retention. Proc. Natl. Acad. Sci. USA 2019, 116, 8734-8739. [CrossRef]

28. Shepard, C.; Pelletier, J.D.; Schaap, M.G.; Rasmussen, C. Signatures of obliquity and eccentricity in soil chronosequences. Geophys. Res. Lett. 2018, 45, 147-153. [CrossRef]

29. Hancock, G.S.; Anderson, R.S. Numerical modeling of fluvial strath-terrace formation in response to oscillating climate. Geol. Soc. Am. Bull. 2002, 114, 1131-1142. [CrossRef]

30. Schirmer, W. Fluviatile Sedimente um Išān Bahrīyāt/Iraq. Bayerische Akademie Wissenschaften Phil.-Hist. Kl. Abh. N.F 1981, 87, 169-196.

31. Schirmer, W. Tells und Tallandschaften im alten Orient. Berl. Beitr. Vorderen Orient 1999, 18, 17-24.

32. Schirmer, W.; Weber, J.; Bachtadse, V.; BouDagher-Fadel, M.; Heller, F.; Lehmkuhl, F.; Panayides, I.; Schirmer, U. Fluvial stacking due to plate collision and uplift during the Early Pleistocene in Cyprus. Cent. Eur. J. Geosci. 2010, 2, 514-523. [CrossRef]

33. Penck, A. Die Eiszeiten in den nördlichen Ostalpen. In Die Alpen im Eiszeitalter; Penck, A., Brückner, E., Eds.; Tauchnitz: Leipzig, Germany, 1902; Volume 1, pp. 23-393.

34. Boesch, H. Bemerkungen zum Terrassen-Begriff. Tijdschr. Ned. Aardrijkskd. Genoot. 1957, 74, $234-238$.

35. Leopold, L.B.; Wolman, M.G.; Miller, J.P. Fluvial Processes in Geomorphology; Freeman: San Francisco, NC, USA, 1964; 522p.

36. Bucher, W.H. "Strath" as a geomorphic term. Science 1932, 75, 130-131. [CrossRef] [PubMed]

37. Fairbridge, R.W. Strath, strath terrace. In Geomorphology. Encyclopedia of Earth Science; Springer: Berlin/Heidelberg, Germany, 1968. [CrossRef]

38. Davis, W.M. Base-level, grade, and peneplain. J. Geol. 1902, 10, 77-111. [CrossRef]

39. Montgomery, D.R. Observations on the role of lithology in strath terrace formation and bedrock channel width. Am. J. Sci. 2004, 304, 454-476.

40. Larson, P.H.; Dorn, R.I. Strath development in small arid watersheds: Case study of South Mountain, Sonoran Desert, Arizona. Am. J. Sci. 2014, 314, 1202-1223. [CrossRef]

41. Bridgland, D.R. River terrace systems in north-west Europe: An archive of environmental change, uplift and early human occupation. Quat. Sci. Rev. 2000, 19, 1293-1303. [CrossRef]

42. Kukla, G.J. Loess stratigraphy of Central Europe. In After the Australopithecines: Stratigraphy, Ecology and Culture Change in the Middle Pleistocene; Butzer, K.W., Isaac, G.L., Eds.; Mouton: The Hague, The Netherlands, 1975; pp. 99-188.

43. Schirmer, W. Die Main-Formation am Obermain mit neotektonischen Versätzen. Geol. Bl. Nordostbayern 2009, 69, 137-163.

44. Ellwanger, D.; Gabriel, G.; Simon, T.; Wielandt-Schuster, U.; Greiling, R.O.; Hagedorn, E.-M.; Hahne, J.; Heinz, J. Long sequence of Quaternary rocks in the Heidelberg Basin Depocentre. Quat. Sci. J. 2008, 57, 316-337.

45. Larson, P.H.; Dorn, R.I.; Faulkner, D.J.; Friend, D.A. Toe-cut terraces: Review and proposed criteria to differentiate from traditional fluvial terraces. Prog. Phys. Geogr. 2015, 39, 417-439. [CrossRef]

46. Forno, M.G.; Lucchesi, S. Relicts of the Pleistocene Po Plain on the Western and Southern slopes of the Turin Hill (NW Italy). J. Maps 2016, 12, 394-406. [CrossRef]

47. Davis, W.M. River terraces in New England. In Rivers and River Terraces; Dury, G.H., Ed.; Macmillan: London, UK, 1970; pp. 36-72.

48. Twidale, C.R. River patterns and their meaning. Earth Sci. Rev. 2004, 67, 159-218. [CrossRef]

49. Roberts, M.C.; Morningstar, O.R. Floodplain formation in a wandering gravel-bed river: Lower Fraser River. B. C. Can. GeoArchaeoRhein 1998, 2, 63-69.

50. Amorosi, A.; Farina, M.; Severi, P.; Preti, D.; Caporale, L.; Di Dio, G. Genetically related alluvial deposits across active fault zones: An example of alluvial fan-terrace correlation from the upper Quaternary of the southern Po Basin, Italy. Sediment. Geol. 1996, 102, 275-295. [CrossRef]

51. Buness, H.; Gabriel, G.; Ellwanger, D. The Heidelberg Basin drilling project: Geophysical pre-site surveys. Quat. Sci. J. 2008, 57, 338-366. 
52. Wegmann, K.W.; Pazzaglia, F.J. Late Quaternary fluvial terraces of the Romagna and Marche Apennines, Italy: Climatic, lithologic, and tectonic controls on terrace genesis in an active orogen. Quat. Sci. Rev. 2009, 28, 137-165. [CrossRef]

53. Schirmer, W. Aufbau und Genese der Talaue. In Das Mainprojekt. Hydrogeologische Studien zum Grundwasserhaushalt und zur Stoffbilanz im Maineinzugsgebiet; Schriftenreihe des Bayerischen Landesamtes für Wasserwirtschaft: München, Germany, 1978; Volume 7, pp. 145-154.

54. Schirmer, W. Der Naturraum Main-Regnitz im Ersten Jahrtausend n. Chr. Schriftenreihe Historischen Vereins Bamberg. 2007, 41, 46-60.

55. Becker, B.; Schirmer, W. Palaeoecological study on the Holocene valley development of the River Main, southern Germany. Boreas 1977, 6, 303-321. [CrossRef]

56. Oshebi, F.M.; El Adli, M.B.; Shaltami, O.R.; Fares, F.F. Alluvial terraces as a measure of vertical movements and neotectonics: Evidences from Wadi Zazah, Al Jabal Al Akhdar, NE Libya. Libyan J. Sci. Technol. 2017, 6, $19-24$.

57. Hargitai, H.; Larson, P.H. Valley Terrace. In Encyclopedia of Planetary Landforms; Hargitai, H., Kereszturi, Á., Eds.; Springer: New York, NY, USA, 2015. [CrossRef]

58. Pazzaglia, F. Fluvial terraces. In Treatise on Geomorphology; Elsevier: Amsterdam, The Netherlands, 2013; pp. 379-412. [CrossRef]

59. Wohl, E. The effect of bedrock jointing on the formation of straths in the Cache la Poudre River drainage, Colorado Front Range. J. Geophys. Res. 2008, 113, F01007. [CrossRef]

60. Stalker, A.; Mac, S. Geology of the terraces at Cochrane, Alberta. Can. J. Earth Sci. 1968, 5, 1455-1466. [CrossRef]

61. Rossato, S.; Monegato, G.; Mozzi, P.; Cucato, M.; Gaudioso, B.; Miola, A. Late Quaternary glaciations and connections to the piedmont plain in the prealpine environment: The middle and lower Astico Valley (NE Italy). Quat. Int. 2013, 88, 8-24. [CrossRef]

62. Schirmer, W. Entstehung der Flusslandschaften als Lebensraum des fruühen Menschen im süddeutschen Schichtstufenland. In Homo Heidelbergensis. Schlüsselfund der Menschheitsgeschichte; Wagner, G.A., Rieder, H., Zöller, L., Mick, E., Eds.; University of Stuttgart: Stuttgart, Germany, 2007; pp. 308-319, 342-360.

63. Schirmer, W. Rhaetian palaeo-Vertisol in Upper Franconia/Germany. J. Appl. Reg. Geol. 2020, 171, 45-70. [CrossRef]

Publisher's Note: MDPI stays neutral with regard to jurisdictional claims in published maps and institutional affiliations.

(C) 2020 by the author. Licensee MDPI, Basel, Switzerland. This article is an open access article distributed under the terms and conditions of the Creative Commons Attribution (CC BY) license (http://creativecommons.org/licenses/by/4.0/). 